\title{
Edmund Blunden and the Incitements of Japan
}

\author{
MIRIAM J. BENKOVITZ
}

When Cyril Beaumont, bookseller and publisher, suggested to Edmund Blunden in the first year of his stay in Tokyo that he produce a "set of poems on Japan," Blunden disparaged the idea. He had found nothing there, after some five months, conducive to poetry. "Japan as presented here in Tokyo," he told Beaumont in a letter of November 17, 1924, "is far from inspiring one to poetry-to blasphemy is the direction!" Blunden conceded, however, that poetry on Japan was not entirely out of the question, and he promised Beaumont anything which "honesty \& plainness need not disown." Blunden admitted that he might "be moved by the relics of the finer dynasties, Kyoto and so forth." He went on, "I can't say knowing that my power of poetry (whatever it is) depends on certain very sudden \& subtle incitements."

Unlike so many English poets, Blunden did not enlarge on those incitements. For him there was no talk of imitation or amplification, no reference to Sir Philip Sidney's golden world or to Wordsworth's "emotion recollected in tranquillity." Indeed, if Blunden had contemplated those "sudden \& subtle incitements" until he could analyze and explain them, he made no effort to do so in the five letters he wrote from Japan to Cyril Beaumont and another 45 to Richard Cobden-Sanderson, friend and publisher, ${ }^{1}$ plus a few letters to one or two others, now in the Special Collections of the Library of The University of Iowa. Nevertheless, what provoked Blunden to poetry is apparent, at least in part, in the manuscript he eventually delivered to Beaumont, Japanese Garland, a book of poems having to do with Japan, even with Tokyo.

If the letters from Tokyo are an indication, Blunden's poetic im-

1 Letters which Blunden wrote to both men shortly before going to Japan and after his return are also at Iowa. 
pulse and indeed his extensive literary output in those Tokyo years came from a constant frustration and discontent. Even before he left his home at Stansfield near Clare in Suffolk, Blunden was troubled about going to Japan. Although he had referred to the possibility in late January and again a week later, ${ }^{2}$ the first confirmation in these letters came in one addressed to Cobden-Sanderson on February 9, 1924: "I am projecting myself ... into the bosom of the Japanese," Blunden wrote. "R. Nichols is leaving his English professorship at Tokyo, I was asked to take it, \&, the salary being fair, I thought I would." But the decision was more momentous than Blunden's mild words imply. Mary Blunden, his wife of only six years, refused to go with him. "Mary is staying here, to my surprise," Blunden told Cobden-Sanderson, "but she prefers to do so, not visualizing Japan as the land of hope \& glory which it now appears to me." And indeed it did appear so. England was racked by the strikes which culminated in the General Strike of 1926. Postwar malaise, which Blunden had tried hard to overcome, lingered with him. More immediately, returns for a man whose income was derived solely from writing were scant. By contrast, Japan offered a sure thing in the way of earnings as well as the allure of the remote East. Englishmen, including the bookish ones, had long gone to far places to earn their way, and Blunden meant to join their ranks. But before the date for his departure was set, his wife had lessened his enthusiasm by her refusal to go with him; and no protest or pleading moved her. He told Cobden-Sanderson that Mary would hear no argument, that for her Stansfield was enough, and she refused to budge. ${ }^{3}$ Ten days later, to Beaumont, Blunden explained his delay in supplying a tardy manuscript by saying that he was "thrown . . out of gear" by the anticipation of Japan. ${ }^{4}$ However predictable a flurry of nerves at so strange and long a journey may be, Blunden was unduly agitated. He spoke of his coming "exile" and confessed that he was "getting worse \& worse, a state of no state overwhelming" him. ${ }^{5}$ He then decided he must delay completion of his life of Leigh Hunt owing to lack of research materials until he returned from Japan. Furthermore he had found a "sad misprint" in his edition of Christopher Smart's poems, and he urged the publisher to issue an erratum

2 Edmund Blunden (hereafter referred to as EB) to Cyril Beaumont. Stansfield, Clare, Suffolk, January 28, 1924; EB to R. A. V. Morris, Stansfield, Clare, Suffolk, February 3, 1924.

3 Cf. EB to Richard Cobden-Sanderson, Stansfield, Clare, Suffolk, February 14, 1924. Blunden's wife, whom he had married in 1918, was Mary Daines Blunden.

4 February 24, 1924.

5 EB to Beaumont, Stansfield, Clare, Suffolk, March 2, 1924. 
slip and insert it in the book. ${ }^{6}$ All in all, these were mournful and harrowing "about-to-be exiled moments."

At last on Friday, March 28, 1924 at 4:10 P.M., Blunden left Liverpool Street Station, London, on the boat-train for Southampton, where he boarded the S. S. Hakone Maru to sail by way of Singapore and Hong Kong half-way round the "swaying" world to Japan. There he came ashore at Yokohama and was promptly "hurried along in the most amiable manner" to see the Maiko Conchological Cabinet. What acquaintance satisfied his own enthusiasm for the conchological in this way or why is lost now, but Blunden never forgot the incident. After viewing the museum, he traveled to Tokyo by rail, a form of transportation in 1924 which had none of the swift, smooth comfort of present times in Japan. Blunden reached Tokyo on May 13, 1924, ${ }^{7}$ and he did not like it.

He began by confessing to Beaumont that he was not precisely "enamoured" of Tokyo. That was early in his stay. But when Blunden had been in Tokyo almost a year, he still had only one good thing to say about his "Japanese experiment"; it was passing. "One day telleth another," he said. "I feel no striving, no new orientation; a few friends support me, and the rest is not silence, but a useless uproar, signifying nothing." 8 And before another year had gone, he lamented that he had ever signed his contract, and he was certain that England was the only place for him. An opportunity to go from Japan to America brought forth a quick determination to go from Japan "to England, if the Gods are good, \& nowhere else." In summer the heat "half melted" him and fleas and mosquitoes plagued him. When winter came, he complained of snow and ice. His asthma troubled him from time to time.

Blunden tried to shelter himself from his environment. Japanese speech seemed a nuisance to learn, and although he had a few phrases which he could "bring out" from time to time, he chose not to work at acquiring more. He asked Cobden-Sanderson, "Can I go through day after day in my present ignorant fashion, observing nothing peculiar

6 Cf. EB to Cobden-Sanderson, Stansfield, Clare, Suffolk, March 18, 1924, March 26, 1924; cf. Christopher Smart, A Song to David with Other Poems, ed, Edmund Blunden, London, 1924.

7 Cf. Edmund Blunden, A Wanderer in Japan. [Tokyo, 1949], p. 93; EB to Cobden-Sanderson, Stansfield, Clare, Suffolk, March 26, 1924.

$8 \mathrm{~EB}$ to Cobden-Sanderson, Tokyo, April 3, 1925; cf. EB to Beaumont, Tokyo, Julv 22, 1924.

9 EB to Cobden-Sanderson, Tokyo, June 28, 1925; cf. EB to Cobden-Sanderson, Tokyo, April 24, 1926. 
in Japanese custom, adding no weird word to my vocabulary?" Blunden's answer to his own question read, "Probably I can."10

Of course he could not. The size and noise of Tokyo are formidable, but its special flavor is undeniable, and it was more pronounced in 1924 before street signs were posted in English, automobiles clogged the streets, and many people adopted Western dress. Blunden reported his tendence to "bow \& scrape after the manner of the country" and an ability to wield chopsticks "well enough to face the future." In any case the food was acceptable. He said that eels and rice "went down well" and the feelers of cuttle fish were "much more Christian eating" than might be imagined. He missed English beer and whiskey, but while saké was "nothing extraordinary," a few cups created a "mildly oiled insouciance." $11 \mathrm{He}$ hardly managed to disregard the small earth tremors, reminders of the massive earthquake of September 1923, which shook Tokyo at intervals. On August 15, he wrote of a minor quake at about two that morning, so "beautiful" that he considered getting out of bed-that bed spread so "reverently" by his "henchman" on the straw-matted floor and covered with a mosquito net which let in only the "more cunning mosquitoes." 12 Living conditions in general were difficult. He was more content with them, however, when he moved in January 1925 from 26 Kitoyamabushi-cho, Uchigome, to the Kikufuji Hotel, Hongo (the section of Tokyo in which the university is located). It was more expensive and it lacked a bar, but all in all it was an improvement on his first address. Still, his description of the place in a letter of November 1 was caustic:

this Hotel is quite a variety, and has its own special features; the staff is constantly altered to suit the latest requirements (of the moneylender opposite), \& the entrance has recently been enriched with a new set of lockers for the clogs of the guests; ping-pong may be indulged in downstairs, while, mingling with the mirth of the champions and their numerous advisers, the chimes of the two stately clocks fill the ear and suggest the time within half an hour either way. Oil stoves may be supplied by the guests; otherwise it is possible that they will be frozen, but the hotel is in touch with a garage stabling an admired motor hearse for the use of departing clients.

Blunden went on about his own room or "cell" as he called it: "The owner's three hats, (two punctured), hang symmetrically above his

10 June 18, 1924; cf. EB to Cobden-Sanderson, Tokyo, May 5, 1925.

11 EB to Beaumont, Tokyo, July 22, 1924; EB to Cobden-Sanderson, Tokyo, July 14, 1924.

12 EB to Cobden-Sanderson, Tokyo, August 15, 1924. 
homely bed; a plate of bananas suggests the Last days of Pompeii . . . and three roses are blooming ... in a ginger jar."13

And at length Blunden looked around him, and he grudgingly recorded something of Japan. The countryside, viewed on "excursions into the hills \& down by the sea" in July 1924, roused his admiration. He admitted that it looked very nice, that the rural cottages had a "Rembrandtesque reminiscence" about them and that "bamboos and pines make very pleasant forests."14 But when Cobden-Sanderson asked for a "vivid description" of Tokyo, Blunden replied with scorn, "What, of paper lanterns, open drains, flower-like ladies, naked brown labourers, grins and stares perpetual, the Imperial Hotel (about half a crown a minute), the cinematograph theatre ... ?"15 He half promised to send a long account of "Tokyanity" when autumn brought cooler weather; but even in the dead of winter he refused to write more about the city because he had "given up swearing." Only in the summer of 1926 did he set down anything about the "cries of 'Eels,' 'Bananas'; drums of exorcisers of devils, bells of newspaper boys," and then he lumped them together as the "usual monotony all round."1 8

That impatient, bored endurance colored his accounts of his teaching, too. Blunden approached it with irony, sometimes distaste. Each day was a chore and when it was done he still had to "contemplate a little more work another day." At last he decided that to "profess" was not his "track," although he had acquired a "strong professorial incrustation-a crabbed o'ergathering of dictatorial didacticism," which, however, he promised to shed. ${ }^{17}$ But the "so-called University" did not measure up to his standards. It had no library "worth the name" and the students were often obtuse and, in accord with their Japanese manners, too polite to admit that what he told them penetrated neither their habits of thought nor the language barrier. But to Blunden his students were men who "have ears \& hear not." He cited as an example of the questions to which his "talents" were currently applied, "Sir, is the owner of a public house called a publisher?" and added that his reply did not matter; for "most of the J. don't believe an honest answer-they stick to their own interpretation."18

13 EB to Cobden-Sanderson, Tokyo, November 1, 1925; cf. EB to CobdenSanderson, Tokyo, January 9 [1925].

14 EB to Cobden-Sanderson, Tokyo, July 14, 1924.

15 EB to Cobden-Sanderson, Tokyo, August 15, 1924.

16 EB to Cobden-Sanderson, Tokyo, July 6, 1926; cf. EB to Cobden-Sanderson, Tokyo, January 9 [1925].

17 EB to Cobden-Sanderson, Tokyo, May 19, 1927, March 8, 1927.

18 EB to Cobden-Sanderson, Tokyo, June 28, 1925. 
Yet, among the "150 unfortunate wretches" to whom he lectured and among his colleagues, Blunden found men to respect and like and work with. While staring "stonily at the horrid truth" of his commitment to Tokyo and recording his discontent with it in letter after letter, Blunden was endlessly busy with literary matters. He read proofs sent him from London, such as those for The Actor by the obscure eighteenth-century English poet Robert Lloyd, published at the Beaumont Press in 1926 with an introductory essay by Blunden. $\mathrm{He}$ attempted to find a Japanese publisher for Cyril Beaumont's The Mysterious Toyshop, which appeared in London in 1924. He recommended the work of colleagues at the Imperial University. He had been in Tokyo less than a year when in January 1925, he initiated English publication of "Master Ishii's little poetry book," a volume which appeared in January 1926, Twelve Poems by Haxon Ishii, and was duly reviewed in the Times Literary Supplement. Similarly Blunden suggested that Cobden-Sanderson consider a collection of verse by an associate, Sherard Vines, a "lively young poet of the Sitwellian tint" whose poems Blunden characterized as "modern \& . . . masterly, full of novel poetic motives and splendid imaginations." Vines's book, Triforium, appeared, too, under Cobden-Sanderson's imprint. ${ }^{19}$ Blunden's greatest enthusiasm, however, was for Takeshi Saito, both colleague and student and, according to Blunden, "scholar, gentleman, and Christian of the first quality." With Saito, Blunden prepared for publication a selection from The Examiner, a paper which in its day had carried essays by Leigh Hunt and Charles Lamb. This was sent to Cobden-Sanderson as was Saito's doctoral dissertation, an essay on Keats's view of poetry. ${ }^{20}$ Blunden worried the book on Leigh Hunt, left unfinished for lack of the British Library; he commenced a collection of William Collins's poems; and he wrote an essay On the Poems of Henry Vaughan. An essay on John Clare delivered as a lecture to an audience of American, English, and Japanese women in October 1924, "by way of ending" his "29th year," was issued in Japan in April or May 1926 as a pamphlet limited to 20 copies. ${ }^{21}$ And Blunden's verses began to appear in journals published in Japan. One

19 EB to Cobden-Sanderson, Tokyo, June 3, 1925, August 28, 1925, January 18, 1925. Cf. Sherard Vines, Triforium, London, 1928; Cobden-Sanderson published Vines's The Pyramid with prefatory verses by Blunden and Yone Noguchi in 1926. For the review of Ishii's Twelve Poems see "New Books and Reprints" in TLS, March 11, 1926, p. 187. Cf. EB to Beaumont, Tokyo, July 22, 1924.

20 EB to Cobden-Sanderson, Tokyo, March 31, 1927; cf. EB to Cobden-Sanderson, Tokyo, May 19, 1927; Takeshi Saito, Keats' View of Poetry [with] an essay on English Literature in Japan by Edmund Blunden, London, 1929.

21 Cf. EB to Cobden-Sanderson, Tokyo, May 19, 1926, October 7, 1926, October 28, 1926, May 24, 1926, July 6, 1926, March 15, 1927. 
called Poetica, made up primarily of materials written in Japanese, from time to time printed poems by Robert Nichols, Blunden's predecessor at the Imperial University, and by Blunden, in English, of course. His verses appeared in the Oriental Literary Times, an elusive periodical, whose existence is known partly because Blunden referred to it in writing to Cobden-Sanderson. In another of those recommendations of the work of his colleagues, Blunden wrote about Neville Whymant, philologist and linguist, who had two manuscripts in search of a publisher. In a letter of May 6, 1925, after presenting Whymant's merits as man and writer and asking the publisher to consider the two manuscripts by Whymant, Blunden added, "Lately he \& I produced a little magazine together but we might have saved our trouble for it was not bought." 22 And when Blunden received a copy of the facsimile edition of Christopher Smart's "Song to David," issued by the Clarendon Press in 1926, he wrote the sonnet which begins,

The Song itself! thus the majestic rhyme

Before the secret-smiling author came;

Thus stood the page where thus he wrote his name

With instinct of his triumph over time.

Blunden might complain that Tokyo did not move him to poetry, but obviously those "sudden \& subtle incitements" of which he spoke were not lacking. Indeed, by mid-June, hardly six weeks after his arrival, he told Cobden-Sanderson that he had written some verses. What verses they were, Blunden did not say, but among them may well have been the slightly flawed but very personal and moving lines of "A 'First Impression' (Tokyo)." Then Blunden's inclination to poetry, indeed to anything literary, began to slacken. In November, in a letter to Cobden-Sanderson, Blunden said, "Literature seems a curious dream in this Tokyo. I am always feeling my arm to make sure I yet subsist." He went on with the complaint usually voiced by the scholar-teacher: "Even reading seems to take hours longer than of old, and as for writing, I no sooner sit down to it than it's time for bed, or the university." $23 \mathrm{He}$ managed, however, despite the "mortifying effect" of Tokyo, to maintain his "habit of versifying."

Some of this versifying produced the poetry which was published as a supplement to Blunden's account of his wartime experiences. $\mathrm{He}$

22 EB to Cobden-Sanderson, Tokyo, May 6, 1925. The Oriental Literary Times appeared in six issues from January 15 to April I, 1925. None of Neville Whymant's books was published by Cobden-Sanderson.

23 EB to Cobden-Sanderson, Tokyo, November 11, 1924; cf. EB to CobdenSanderson, Tokyo, June 18, 1924. See also the autograph signed copy of Blunden's sonnet "On receiving from the Clarendon Press the new Facsimile edition of Christopher Smart's "Song to David" " dated from Tokyo, "Dec. 1926." 
had tried to write such a book as early as 1918 , but he abandoned it, an incomplete manuscript filled with false gaiety and unexamined detail. ${ }^{24}$ In Tokyo, removed in time and place from the world of the war, Blunden worked at this book intermittently throughout most of his stay in Japan. He first mentioned it from there in a letter of September 6, 1924 as a "prose + verse work" which was "coming on." He added that he doubted its practicality as a publishing venture, but he meant to get it done and submit it to Cobden-Sanderson. In April of the next year, Blunden referred again to the poetry for the book. He had first planned to have it ready for the publisher in 1926, but not until 1927, well after it was finished, did he speak of sending the manuscript. At that time Blunden named the book-a "large manuscript . . . called 'Undertones of War'"-and described it-a "prose record with a supplement of some thirty poems." And even then the book needed corrections and additions from Blunden's journals, left in England. ${ }^{25}$

Other poetry writing was for a collection under preparation before Blunden left England. Since it was to include only poems written since The Shepherd, a book of his verse awarded the prestigious Hawthornden Prize in 1922, Blunden called it "New Verse." From Tokyo in late summer 1924, he remarked on his eagerness to get the manuscript of the book to Cobden-Sanderson and went on to talk about the job of selecting from the hundred or so poems already in hand. These included, Blunden said, "quite a strong detachment" of unpublished poems, pieces published in magazines, and pieces already given to Cyril Beaumont for other publication. ${ }^{26}$

The selections already in Beaumont's hands had been delivered early in March 1924. These were for a volume to be called Masks of Time and produced, as To Nature had been, in a limited edition. Six months after publication, the rights in the poems of Masks of Time returned to Blunden and thus became available for inclusion in whatever volume he chose. But no date could be set for reversion of rights and a second publication until Masks of Time appeared. As late as September 6, 1924, Blunden had heard nothing from Beaumont, and the proofs did not reach Tokyo until November 17.27

Nevertheless Blunden had made his selection for "New Poems" by

24 Cf. Edmund Blunden, "Preliminary" in Undertones of War, London, 1928; Miriam J. Benkovitz, "Edmund Blunden's Ghosts," in Columbia Library Columns, February 1978, pp. 14-22.

25 EB to Cobden-Sanderson, Tokyo, March 31, 1927; cf. EB to Cobden-Sanderson, Tokyo, April 3, 1925.

26 April 15, 1924.

27 Cf. EB to Beaumont, Tokyo, November 17, 1924. 
mid-August 1924 and on September 6 he promised to send it at once. ${ }^{28}$ Eight months later it was still in Tokyo, but he declared in a letter of May 5, 1925 that he was "posting by this post" the manuscript, now called English Poems. ${ }^{29}$ With that title, it came out in January 1926.

Two pieces which first appeared in English Poems later introduced Japanese Garland, the "set of poems on Japan" for which Beaumont had asked. These two are "A 'First Impression' (Tokyo)" and "The Daimyo's Pond." That they serve both books helps to clarify the "sudden \& subtle incitements" which Blunden maintained to be the source of his "power of poetry." Obviously it was not a question of place. In Retreat, his next volume of verse which he took with him in manuscript when he left Japan in 1927, Blunden carefully explained that no poems on "Japanese topics and impulses" appeared in that volume; he had set such pieces aside for "separate or subsequent presentation." 30 These were the heart of Japanese Garland, obviously composed mostly in Japan but not complete when he left there. He added to it well after his return to England. On January 4, 1928, from Cowlinge, Newmarket, Surrey, Blunden sent Beaumont a new poem to be included in Japanese Garland and offered to send still another in a few days if there was room for it. In other words, Blunden could write about Japanese topics in Japan as he had about English ones in England. But he could also write about Japanese topics in England or vice versa. The sonnet about Christopher Smart's "Song to David," composed in December $1926^{31}$ and indeed the whole of Retreat as well as Japanese Garland demonstrate the irrelevance of place.

Japanese Garland makes apparent not only the fact that for Blunden the incitement might occur anywhere but also that the "topics and impulses" were not the poem. They served as something to talk about ostensibly. Most of Blunden's poems are about his own emotions-"The Daimyo's Pond" about loneliness, "A 'First Impression' (Tokyo)" about his grief for a dead child and his joy in two living ones. Even "The Author's Last Words to his Students" is not about his students but about himself. In other words, Japanese Garland puts Blunden in the mainstream of English poets classified as romantic: Clare, Shelley, Keats. And his poetry, as Wordsworth, another romantic, defined it was the "spontaneous overflow of powerful feeling." That feeling was provoked by some object-a pond, a tempest, a walk in Nara-and the emotion was correlated with it so that his ap-

28 Cf. EB to Cobden-Sanderson, Tokyo, September 6, 1924, August 15, 1924.

29 Cf. EB to Cobden-Sanderson, Tokyo, May 5, 1925.

30 Edmund Blunden, ["Author's Note"] in Retreat, London, 1928, p. [7].

31 Cf. EB to Beaumont, Cowlinge, Newmarket, Suffolk, January 4, 1928. 
parent incitement is the object and the real one the emotion which it produces and with which it correlates. Blunden himself recognized the fact when he spoke of the "inward sequence" of the poems in Japanese Garland and "the strong family likeness between all." 32

Although Blunden had more to say about his reaction to Japan after a second visit in the 1940s, Japanese Garland is his final word about his stay there from May 1924 to August 1927. Contrary to his expectations, he found numerous incentives to poetry. He found them even in Tokyo, and while the sharp distaste for the city, so blatant in Blunden's letters, is missing from the poems, they imply no approval. "Building the Library, Tokyo University Night Scene" welcomes this "one more home" for the "great Muse"; but one of the more offensive qualities of Tokyo, a careless cruelty, is implicit in the title "On A Small Dog, thrust out in a Tokyo street soon after his birth and rescued in vain." The "vivid description" which he had derided to Cobden-Sanderson, Blunden supplied in "Ornamentations":

The curving cranes with serpent necks

Knotted on these enamelled streams,

The gloating mouths thrust out to vex

The red-eyed war-god's frenzy dreams,

The inscrutable and dog-like grin

of demi-lions lock me in!

That is a vivid first stanza. Perhaps more evocative of place and more typical of Blunden is the dark majesty he found outside Tokyo when he sailed the Inland Sea of Japan:

Here in the moonlit sea,

While swift we fly, while tranced we gaze,

The fishers wind their ancient ways:

Now like sea-lilies loom their luring sails,

Or heaven's envoys walking fountained vales;

And now by one deflection dark,

Like waiting vultures of the night

Each pirate blackness skulks, a murderous mark

Begotten by a thing of light,

Like apprehension's baffling destiny. ${ }^{33}$

32 EB to Beaumont, Cowlinge, Newmarket, Suffolk, May 3, 1928.

33 Edmund Blunden, "Inland Sea," in Japanese Garland, London, 1928, p. 26. 


\section{Moments}

\section{Jn a Park at Kyoto}

Beneath the leaves I lie, and read, and glance Across the sunksams there the children dance, And boy and girl run races; then $I$ try Mty book again. A bronze head, a hight eye Consider mie. This lizard by his look Has come to $k$ allowed to share my book.

\section{The Inn Window, Tukuoka}

Fierce came the snow,and is gone like e dream.

To the sunbeam glancing

The midges are dancing,-

And still on the blue sky

the plum Hossoms glearm.

\section{In llshigome}

This year the nightingale of bird-Jayan Began to sing here, and he hut began; To find the callse for his remismen \&

Am most incompectemt and stall aut hy;

Let him go warble through his trills and dales Takeshi's library's rich in mightingales.

$$
\begin{aligned}
& \text { [-akeshie Saito, of Joryo } \\
& \text { Univensity fa. }
\end{aligned}
$$

Three short poems of Japanese incitement in the handwriting of Edmund Blunden (1896-1974). It is possible that these may be Blunden's transcriptions of verses by Takeshi Saito rather than his own compositions. Reprinted by permission of A. D. Peters \& Co. Ltd. 


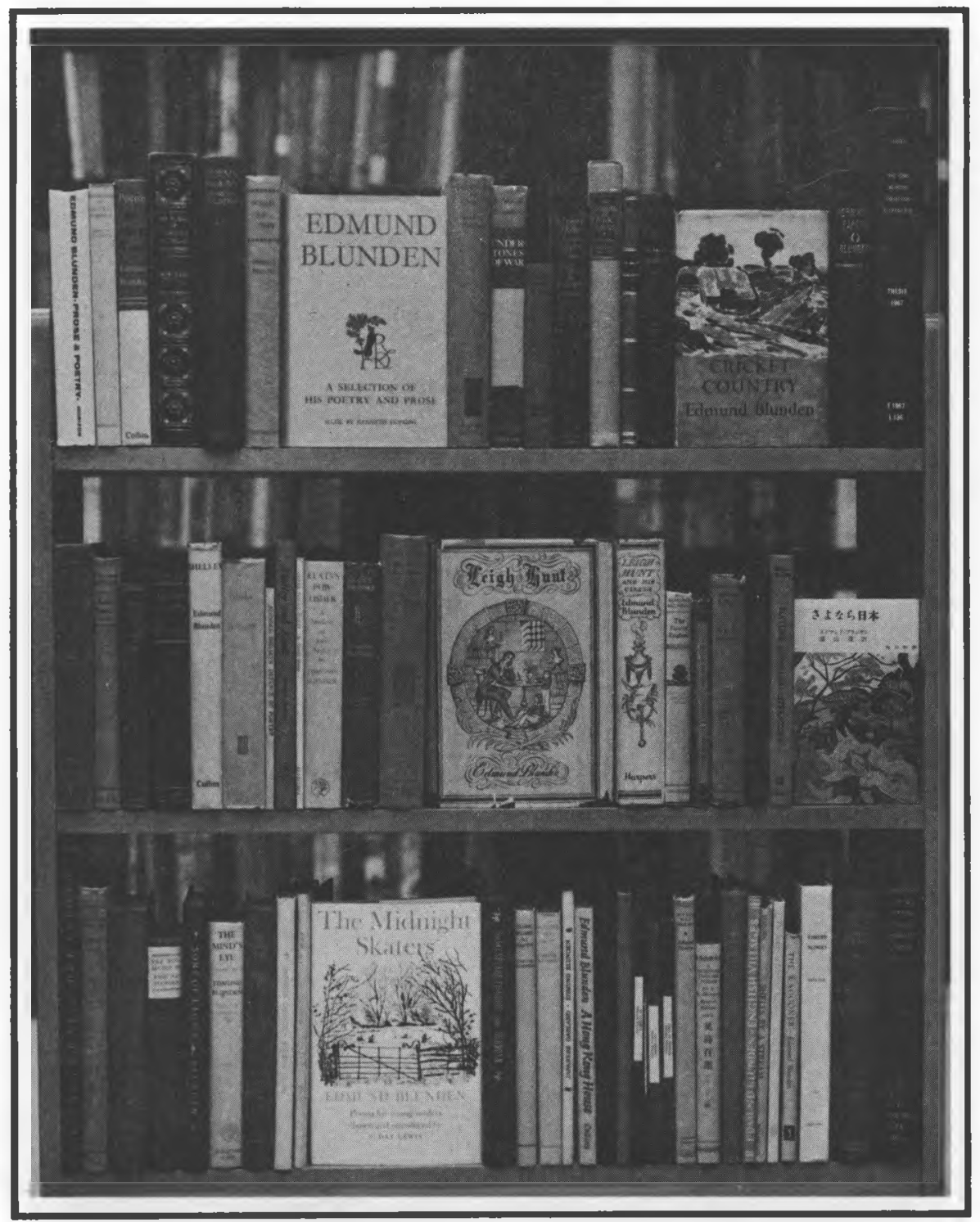

A selection of books from the Edmund Blunden Collection in The University of Iowa Libraries. This collection presently includes some 330 printed volumes, 120 pamphlets or reprints, and an estimated one thousand manuscript drafts of letters, poems, and essays. 


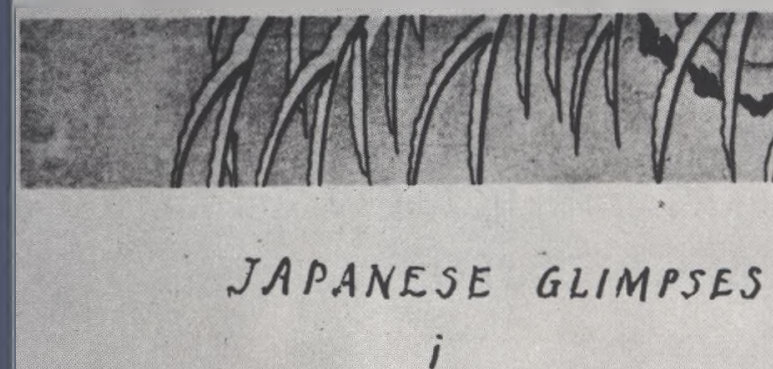

Mevrily under the trees they ran Hunting for mushrooms; every day The children's endless adventure legan But Jime lives in those woods, they say.

$$
\text { ii }
$$

Tell me who can if Memory most will keep The splendour of that snorry mountain height, Or noon's just-murmuring oceam haff asleep. or this black butterfly and lily white.

\section{iii}

An enchanter called this dream-inle from The summer wave;

And in a long-forgotten grave

He sleeps; the dream abows the foors stands, rock and grove, until he cerne.

Edmuni Alunden 